\title{
Isolation of Bacteria from the Vaginal Aspirates of Cyclic, Acyclic, Endometritic and Pregnant Crossbred Cows
}

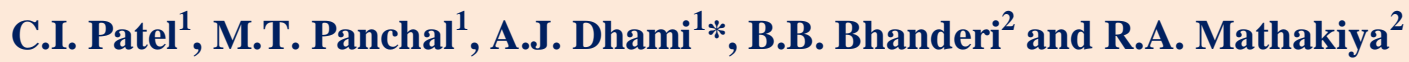 \\ ${ }^{1}$ Department of Animal Reproduction, Gynaecvology \& Obstetrics, College of Veterinary \\ Science and Animal Husbandry, Anand Agricultural University, Anand, \\ Gujarat - 388 001, India \\ ${ }^{2}$ Department of Veterinary Microbiology, College of Veterinary Science and Animal \\ Husbandry, Anand Agricultural University, Anand, Gujarat - 388 001, India \\ *Corresponding author
}

\section{Keywords \\ Bacterial isolates, Cattle vagina, Estrus cycle, Acyclic, Endometritis, Pregnancy}

Article Info

Accepted:

07 February 2019

Available Online:

10 March 2019

\section{A B S T R A C T}

A study was carried out on vaginal secretions/aspirates from infertile (acyclic and endometritic) crossbred cows from field and healthy cyclic as well as pregnant crossbred cows of University farm to identify the vaginal microorganisms based on routine cultural examination. The work was carried out on total 36 crossbred cows covering six each regular cyclic (proestrus, estrus, metestrus, diestrus), acyclic, endometritic and 3, 6 and 9 months pregnant animals. The samples of cervico-vaginal mucus/discharge during estrus/ endometritis, and vaginal washings during other phases of estrous cycle as well as pregnancy were collected aseptically using syringe and pipette method. The samples obtained were soon processed for cultural isolation on Blood agar and MacConkey agar, and identified using Gram's staining and biochemical tests. Bacteria were recovered from all 54 vaginal samples $(100 \%)$ of cows with different physio-pathological status. During the follicular phase of estrous cycle, the most predominant bacteria isolated were Bacillus Spp., followed by Corynebacterium Spp., Staphylococcus Spp. and Streptococcus Spp., whereas during luteal phase the most predominant bacteria were Staphylococcus Spp. followed by Corynebacterium Spp., Bacillus Spp., E. coli and Streptococcus Spp. The most predominant vaginal bacterial isolates during pregnancy in descending order were Staphylococcus Spp., Bacillus Spp., Streptococcus Spp., Klebsiella, E. coli and Pseudomonas. The vaginal aspirates of acyclic cows contained Streptococcus Spp., Bacillus Spp. and Staphylococcus Spp., Corynebacterium Spp., E. coli, and Micrococcus, whereas in endometritis the major isolates were Staphylococcus Spp., Bacillus Spp., Streptococcus Spp., E. coli, Salmonella and Corynebacterium. The findings reflected rich bacterial diversity in the vagina of crossbred cattle with varied physio-pathological conditions.

\section{Introduction}

Optimum reproductive performance is essential for well managed and profitable dairy farms (Nebel and Jobst, 1998). Fertility of cow is affected by many specific and nonspecific pathogens of the genital tract. Cervical mucus discharge (CMD) is a 
mechanical barrier against pathogens of the uterus. CMD of cows and heifers with abnormal appearance in estrous cycle is one of the factors that farmers or inseminators consider as a suppressor of reproductive performance (Mahmoudzadeh et al., 2001). Endometritis in cows, characterized clinically by the presence of pus in the vagina (Sheldon et al., 2002) is associated with lower first service conception rate, increased open days, and more culls for failure to conceive (LeBlanc et al., 2002). According to various researchers (Fernandez et al., 2006), the normal vaginal microflora mostly comprises aerobic bacteria (Staphylococcus, Streptococcus and coliforms), anaerobic bacteria (Lactobacillus, Fusobacterium, and Pepto-streptococcus) and proportionately less fungi (Aspergillus and Penicillium). Enterobacteriaceae, especially $E$. coli have been isolated from the urogenital tract of cattle in low numbers (Otero et al., 2000). Nevertheless, E. coli is well known to cause endometritis and infertility in cattle (Sheldon et al., 2002). The present work was aimed to know the normal bacterial flora from the genital discharges/aspirates of normal cyclic and pregnant cows, as well as those suffering from anestrus and endometritis to establish their relation with the status of reproduction.

\section{Materials and Methods}

The investigation was carried out on the vaginal secretions/aspirates of infertile crossbred cows under field from village Chikhodra of Anand taluka and healthy cyclic as well as pregnant crossbred cows of Livestock Research Station, AAU, Anand from August 2017 to June 2018. The work was carried out on total 36 crossbred cows covering six each regular cyclic (proestrus, estrus, metestrus, diestrus), acyclic, endometritic and 3,6 and 9 months pregnant animals. The samples of cervico-vaginal mucus during estrus, and vaginal washings during other phases of estrous cycle, i.e., proestus, metestrus, diestrus, and anestrus as well as pregnancy were collected aseptically, using sterilized $10 \mathrm{ml}$ glass pipette and $60 \mathrm{ml}$ syringe, employing recto-vaginal technique of Panangala et al., (1978). Similarly the vaginal discharge samples from endometritic cows were also obtained aseptically. For obtaining vaginal mucus / discharge / washing, the pointed end of glass pipette was connected to a $60 \mathrm{ml}$ syringe with rubber junction. For animals other than in estrus or endometritic, $30 \mathrm{ml}$ sterile normal saline solution was first infused in the vaginal fornix, massaged per rectally for few minutes and was again aspirated with the same pipette aseptically.

The vaginal samples $(n=54)$ obtained were processed for cultural isolation within an hour of collection. The aim of study was to identify the vaginal microorganism during different physio-pathological conditions of cattle based on routine culture of vaginal samples on blood agar and MacConkey agar plates (Cruickshank, 1965). The isolates obtained were subjected to detailed identification using Gram's staining and biochemical tests such as oxidase, $\mathrm{KOH}$ and catalase tests. The results of DNA extracted from all the vaginal samples and its metagenomics up to phyla, genera and species obtained using NGS and MG RAST library have been reported separately (Patel, 2018). The per cent frequency of various isolates obtained from different samples was worked out and is reported in this paper.

\section{Results and Discussion}

The details of vaginal bacterial flora of crossbred cows obtained on cultural examination during different phases of estrous cycle, anestrum, endometritis and 3, 6 and 9 months pregnancy are furnished in Table 1. Bacteria were recovered from all 54 vaginal samples $(100 \%)$ of cows with different 
physio-pathological status. In all, 170 bacterial isolates were obtained from 54 samples.

\section{Bacterial isolates from vagina of cyclic cows}

During the follicular phase (proestrus and estrus) of estrous cycle, the most predominant bacteria isolated were Bacillus Spp. (22.58\%) followed by Corynebacterium Spp., Staphylococcus Spp. and Streptococcus Spp. (19.35\% each), E. coli and Salmonella (6.45\% each), and Micrococcus and vaginal yeast (3.23\% each), making 18.24 per cent of the total 170 bacterial isolates. During luteal phase (metestrus and diestrus) of estrous cycle, the most predominant bacteria were Staphylococcus Spp. (19.05\%) followed by Corynebacterium Spp. (14.29\%), Bacillus Spp., E. coli and Streptococcus Spp. (11.90\% each), Micrococcus (9.52\%), Salmonella (7.14\%), and Klebsiella, Proteus and vaginal yeast $(4.76 \%$ each), making 24.71 per cent of the total 170 bacterial isolates. Thus, based on the total bacterial isolates of estrous cycle, follicular and luteal phase constituted 42.47 and 57.53 per cent, respectively. These findings supported the common consensus that the estrogenic phase of cycle inhibits vaginal bacterial isolates through improved local defense mechanism. In the present study, E. coli, Staphylococcus, Streptococcus, Corynebacterium Spp., Bacillus Spp., Salmonella, Micrococcus and Yeast were the commonest isolates throughout the estrous cycle of cows. However, Proteus and Klebsiella were not isolated during follicular phase, but were isolated during luteal phase of the estrous cycle. These organisms could, therefore, be considered as a part of the normal vaginal bacterial flora of the cow. The stage of the cycle did not alter the types of bacteria isolated, but increased numbers were present in luteal phases of the estrous cycle and pregnancy.
During estrous cycle, the dominance of the estrogen during the follicular phase of estrous cycle, increases the rate of migration of leucocyte into the uterine lumen and thus increases the bactericidal activity. El-Jakee $e t$ al., (2008) isolated 22.47 per cent bacteria during follicular phase and 77.53 per cent during luteal phase of normal estrous cycle. However, Vlcek and Svobodova (1985) reported comparable findings of 40.90 per cent samples with bacterial isolates during follicular phase and 35.36 per cent during luteal phase of normal cycle. In the present study, bacteria were recovered from all (100\%) of the 24 samples of cyclic crossbred cows (Table 1). Similar results were also obtained by El-Jakee et al., (2008), who reported bacterial culture from 100 per cent of vaginal samples during normal estrous cycle. However, these findings are in contrary to the previous reports of 53.9 (Ocando et al., 2010; Zambrano-Nava et al., 2011) and 54.5 (Ahuja et al., 2017) per cent cultural positive samples from normal fertile cows.

\section{Bacterial isolates from vagina of acyclic and endometritic cows}

The vaginal aspirates of acyclic cows were positive for Streptococcus Spp. (22.22\%), Bacillus Spp. and Staphylococcus Spp. (16.67\% each), Corynebacterium Spp., E. coli, and Micrococcus (11.11\% each), and Salmonella and Klebsiella (5.56\% each), constituting 10.59 per cent of the total bacterial isolates, whereas the vaginal discharges of endometritis cows, showed Staphylococcus Spp. (17.39\%), Bacillus Spp., Streptococcus Spp., E. coli, Salmonella and Klebsiella (13.04\% each), and Corynebacterium Spp. and Proteus $(8.70 \%$ each), constituting 13.53 per cent of the total bacterial isolates. This higher frequency of bacterial isolates from cases of endometritis is justified due to apparent genital infection. 
Table.1 Cultural isolates from vaginal discharges/aspirates of crossbred cows during different reproductive physio-pathological status ( $\mathrm{n}=6$ each)

\begin{tabular}{|c|c|c|c|c|c|c|c|c|c|c|c|c|c|c|}
\hline \multirow{2}{*}{\multicolumn{2}{|c|}{ Stage }} & & \multicolumn{11}{|c|}{ Isolated organisms } & \multirow{2}{*}{$\begin{array}{c}\text { Total } \\
\text { no. of } \\
\text { isolates }\end{array}$} \\
\hline & & & $\begin{array}{c}\text { Bacillus } \\
\text { Spp. }\end{array}$ & $\begin{array}{l}\text { Corynebact- } \\
\text { erium Spp. }\end{array}$ & E.coli & Klebsiella & $\begin{array}{l}\text { Pseudo- } \\
\text { monas }\end{array}$ & $\begin{array}{l}\text { Staphylo- } \\
\text { coccus }\end{array}$ & Salmonella & $\begin{array}{l}\text { Strepto- } \\
\text { coccus }\end{array}$ & $\begin{array}{l}\text { Micro- } \\
\text { coccus }\end{array}$ & Yeast & Proteus & \\
\hline \multirow{4}{*}{ 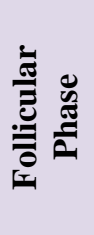 } & \multirow[t]{2}{*}{ Proestrus } & No. & 4 & 3 & 2 & 0 & 0 & 3 & 1 & 3 & 0 & 0 & 0 & 16 \\
\hline & & $\%$ & 25.00 & 18.75 & 12.50 & 0.00 & 0.00 & 18.75 & 6.25 & 18.75 & 0.00 & 0.00 & 0.00 & 9.41 \\
\hline & \multirow[t]{2}{*}{ Estrus } & No. & 3 & 3 & 0 & 0 & 0 & 3 & 1 & 3 & 1 & 1 & 0 & 15 \\
\hline & & $\%$ & 20.00 & 20.00 & 0.00 & 0.00 & 0.00 & 20.00 & 6.67 & 20.00 & 6.67 & 6.67 & 0.00 & 8.82 \\
\hline \multirow{8}{*}{ 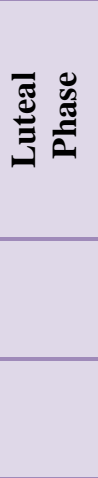 } & \multirow[t]{2}{*}{ Metestrus } & No. & 3 & 4 & 2 & 0 & 0 & 4 & 2 & 3 & 2 & 0 & 0 & 20 \\
\hline & & $\%$ & 15.00 & 20.00 & 10.00 & 0.00 & 0.00 & 20.00 & 10.00 & 15.00 & 10.00 & 0.00 & 0.00 & 11.76 \\
\hline & \multirow[t]{2}{*}{ Diestrus } & No. & 2 & 2 & 3 & 2 & 0 & 4 & 1 & 2 & 2 & 2 & 2 & 22 \\
\hline & & $\%$ & 9.09 & 9.09 & 13.64 & 9.09 & 0.00 & 18.18 & 4.55 & 9.09 & 9.09 & 9.09 & 9.09 & 12.94 \\
\hline & \multirow[t]{2}{*}{ Acyclic } & No. & 3 & 2 & 2 & 1 & 0 & 3 & 1 & 4 & 2 & 0 & 0 & 18 \\
\hline & & $\%$ & 16.67 & 11.11 & 11.11 & 5.56 & 0.00 & 16.67 & 5.56 & 22.22 & 11.11 & 0.00 & 0.00 & 10.59 \\
\hline & \multirow[t]{2}{*}{ Endometritic } & No. & 3 & 2 & 3 & 3 & 0 & 4 & 3 & 3 & 0 & 0 & 2 & 23 \\
\hline & & $\%$ & 13.04 & 8.70 & 13.04 & 13.04 & 0.00 & 17.39 & 13.04 & 13.04 & 0.00 & 0.00 & 8.70 & 13.53 \\
\hline \multirow{8}{*}{ 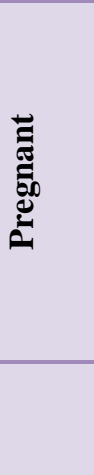 } & \multirow[t]{2}{*}{3 Months } & No. & 4 & 0 & 3 & 3 & 2 & 4 & 2 & 3 & 0 & 0 & 1 & 22 \\
\hline & & $\%$ & 18.18 & 0.00 & 13.64 & 13.64 & 9.09 & 18.18 & 9.09 & 13.64 & 0.00 & 0.00 & 4.55 & 12.94 \\
\hline & \multirow[t]{2}{*}{6 Months } & No. & 3 & 2 & 0 & 2 & 2 & 3 & 2 & 3 & 0 & 0 & 2 & 19 \\
\hline & & $\%$ & 15.79 & 10.53 & 0.00 & 10.53 & 10.53 & 15.79 & 10.53 & 15.79 & 0.00 & 0.00 & 10.53 & 11.18 \\
\hline & \multirow[t]{2}{*}{9 Months } & No. & 2 & 0 & 2 & 2 & 1 & 4 & 0 & 2 & 1 & 0 & 1 & 15 \\
\hline & & $\%$ & 13.33 & 0.00 & 13.33 & 13.33 & 6.67 & 26.67 & 0.00 & 13.33 & 6.67 & 0.00 & 6.67 & 8.82 \\
\hline & \multirow[t]{2}{*}{ Total } & No. & 27 & 18 & 17 & 13 & 5 & 32 & 13 & 26 & 8 & 3 & 8 & 170 \\
\hline & & $\%$ & 15.88 & 10.59 & 10.00 & 7.65 & 2.94 & 18.82 & 7.65 & 15.29 & 4.71 & 1.76 & 4.71 & 100.00 \\
\hline
\end{tabular}


The bacterial species isolated in the present study from acyclic cows (100\%) agreed with previous reports of El-Jakee et al., (2008) and Wagener et al., (2015). Similarly, the results of endometritis samples are in agreement with the findings of El-Kader and Shehata (2001) and Barman et al., (2013). However, these findings are in contrary to Patel et al., (2009), Moges et al., (2013) and Udhayavel et al., (2013). They reported only 55 to 92 per cent samples showing bacterial growth in endometritic crossbred cows. Some researchers (Cohen et al., 1996; Petit et al., 2009) however isolated Arcanobacterium pyogenes and Actinomyces pyogenes as the most predominant bacteria. In a recent study on crossbred cows with puerperal endometritis $(25 \pm 2$ days, $n=30)$ and repeat breeding $(n=40)$, only 63.3 and 70 per cent cows, respectively, yielded mixed bacterial isolates, whereas the rest of the samples were sterile (Raval et al., 2018). From the above discussion it is easily understood that most of the endometritic and pyogenic cases and/or uterine infections are caused by $E$. coli, Staphylococcus Spp., Streptococcus Spp., Klebsiella Spp. and Proteus Spp.

\section{Bacterial isolates from vagina of pregnant cows}

The isolated bacteria from vaginal aspirates of 3 months pregnant cows were Bacillus Spp. and Staphylococcus Spp. (18.18\% each), Streptococcus Spp., E. coli and Klebsiella (13.64\% each), Pseudomonas and Salmonella (9.09\% each), and Proteus (4.55\%), comprising 12.94 per cent of the total bacterial isolates. Another 11.18 per cent of the bacteria isolated were from six months pregnant cows with frequency of Bacillus Spp., Staphylococcus Spp. and Streptococcus Spp. as 15.79 per cent each, and Corynebacterium Spp., Pseudomonas, Klebsiella, Salmonella and Proteus 10.53 per cent each. Moreover, the vagina of nine months pregnant cows revealed Staphylococcus Spp. (26.67\%), Bacillus Spp., Streptococcus Spp., E. coli and Klebsiella (13.33\% each), and Micrococcus, Pseudomonas and Proteus $(6.67 \%$ each, Table 1), constituting 8.82 per cent of the total bacterial isolates.

In comparison to 100 per cent of vaginal samples of pregnant cows showing bacterial growth in present study, El-Kader and Shehata (2001) and Jadon et al., (2005) reported 92.30 and 89.90 per cent bacterial positive samples in pregnant cows. There was also decline in the frequency of vaginal isolates with advancing gestation as reported by El-Jakee et al., (2008), who found the most predominant isolates as $E$. coli followed by Micrococcus Spp. El-Kader and Shehata (2001) also isolated family Enterobacteriaceae as the most predominant bacterial isolates followed by untypable $E$. coli, Enterobacter aerogenes and Klebsiella oxytoca from the genital tract of pregnant cows. Jadon et al., (2005) isolated E. coli (17.7\%), Klebsiella Spp. (5.81\%), Staphylococcus (12.79\%), and Bacillus Spp. $(9.30 \%)$ from the genital tract of pregnant buffaloes $(n=40)$. Further they also reported that more number of isolates was found in early stage $(42.08 \%)$ than in last stage $(15.83 \%)$ of gestation.

It is thus concluded that the vaginal cavity of healthy cyclic and pregnant as well as acyclic and endometritic cows shows a dynamics of bacterial isolates according to ovarian/ endocrine status, signifying its role in physiopathology of reproduction in crossbred cattle.

\section{Acknowledgement}

We are grateful to the Dean of the Veterinary Faculty and University authorities for the facilities provided and Research Scientist \& Head, LRS, AAU, Anand for cooperation while samples collection for this work. 


\section{References}

Ahuja, A.K., Cheema, R.S., Narang, D. and Dhindsa, S.S. 2017. Bacterial pathogens and antibiotic susceptibility patterns of cervico-vaginal discharges in crossbred repeat breeding cows. Int. J. Curr. Microbiol. App. Sci., 6(6), 1769-1775.

Barman, P., Yadav, M.C., Bangthai, A. and Kumar, H. 2013. Antibiogram of bacteria isolated from bovine endometritis. Vet. Res. International, 1, 20-24.

Cohen, R.O., Colodner, R., Ziv, G. and Keness, J. 1996. Isolation and antimicrobial susceptibility of obligate anaerobic bacteria recovered from the uteri of dairy cows with retained fetal membranes and post-parturient endometritis. Zoonoses Public Health, 43(1-10), 193-199.

Cruickshank, R. 1965. Medical Microbiology. $11^{\text {th }}$ edn. The English Language Book Society and E \& S Livingstone Ltd., Great Britain.

El-Jakee, J.A., Ahmed, W.M., El-Seedy, F.R. and El-Moez, S.A. 2008. Bacterial profile of the genital tract in female buffaloes during different reproductive stages. Global Vet., 2(1), 7-14.

El-Kader, H.A. and Shehata, S.H. 2001. Bacteriological evaluation of vaginal discharges in cows with endometritis and clinically healthy heifers in Assiut governorate. Assiut Univ. Bull. Environ. Res, 4(2), 45-53.

Fernández, M.A., Silveira, P., Enrique, A., López, R. and Omar, F. 2006. Uterine infections in bovine female. Revista Electrónica de Veterinaria Redvet ${ }^{\circledR}$, 7, 1695-7504. http://www. veterinaria.org /revistas/redvet/n101006.html.

Jadon, R. S., Dhaliwal, G. S. and Jand, S. K. (2005). Prevalence of aerobic and anaerobic uterine bacteria during peripartum period in normal and dystocia-affected buffaloes. Anim. Reprod. Sci., 88(3-4): 215-224.

LeBlanc, S.J., Duffield, T.F., Leslie, K.E., Bateman, K.G., Keefe, G.P., Walton, J.S. and Johnson, W.H. 2002. Defining and diagnosing postpartum clinical endometritis and its impact on reproductive performance in dairy cows. J. Dairy Sci., 85(9), 2223-2236.

Mahmoudzadeh, A.R., Tarahomi, M. and Fotoohi, H. 2001. Effect of abnormal vaginal discharge at estrus on conception rate after artificial insemination in cows. Anim. Sci., 72(3), 535-538.

Moges, N., Regassa, F., Yilma, T. and Unakal, C.G. 2013. Isolation and antimicrobial susceptibility of bacteria from dairy cows with clinical endometritis. J. Reprod. Fert., 4(1), 04-08.

Nebel, R.L. and Jobst, S.M. 1998. Evaluation of systematic breeding programs for lactating dairy cows: A review. $J$. Dairy Sci., 81(4), 1169-1174.

Ocando, J.B., Nava, S.Z., Nava, J. and Martinez, G.P. 2010. Profile of vaginal bacterial flora: A potential risk for reproduction in Criollo Limonero cows. Revista Científica., 20(3), 227234.

Otero, C., Saavedra, L., Silva de Ruiz, C., Wilde, O., Holgado, A.R. and NaderMacías, M.E. 2000. Vaginal bacterial microflora modifications during the growth of healthy cows. Letters in Appl. Microbiol., 31(3), 251-254.

Panangala, V.S., Fish, N.A. and Barnum, D.A. 1978. Microflora of the cervicovaginal mucus of repeat breeder cows. The Canadian Vet. J., 19(4), 83.

Patel, C.I. 2018. Study on reproductive microbiota in cyclic, acyclic and endometritic crossbred cattle. M.V.Sc. 
Thesis, Anand Agricultural University, Anand, Gujarat, India.

Patel, P.P., Panchal, M.T., Kalyani, I.H. and Kavani, F.S. 2009. Antibiotic sensitivity spectrum of bacterial isolates from cervico-vaginal mucus of postpartum rural buffaloes. Intas Polivet, 10(1), 29-31.

Petit, T., Spergser, J., Rosengarten, R. and Aurich, J. 2009. Prevalence of potentially pathogenic bacteria as genital pathogens in dairy cattle. Reprod. Dom. Anim., 44, 88-91.

Raval, S.R., Panchal, M.T., Dhami, A.J., Hadiya, K.K. and Bhanderi, B.B. 2018. Studies on bacterial isolates and their antibiogram from genital discharges of puerperal and repeat breeding crossbred cows. Indian J. Anim. Reprod., 39(2), 58-60.

Sheldon, I., Noakes, D. and Rycroft, A. 2002. The vagina on uterine bacterial contamination. Vet. Rec., 151, 531534.
Udhayavel, S., Malmarugan, S., Palanisamy, K. and Rajeswar, J. 2013. Antibiogram pattern of bacteria causing endometritis in cows, Vet. World, 6(2), 100-102.

Vlček, Z, and Svobodová, R. 1985. Occurrence and antibiotic sensitivity of bacteria present in the cervical mucus of cows in late puerperium and postpuerpertal period. Acta Vet. Brno, 54(1-2), 91-97.

Wagener, K., Prunner, I., Pothmann, H., Drillich, M. and Ehling-Schulz, M. 2015. Diversity and health status specific fluctuations of intrauterine microbial communities in postpartum dairy cows. Vet. Microbiol., 175(2-4), 286-293.

Zambrano-Nava, S., Boscán-Ocando, J. and Nava, J. 2011. Normal bacterial flora from vagina of Criollo Limonero cows. Trop. Anim. Health Prod., 43(2), 291-294.

\section{How to cite this article:}

Patel, C.I., M.T. Panchal, A.J. Dhami, B.B. Bhanderi and Mathakiya, R.A. 2019. Isolation of Bacteria from the Vaginal Aspirates of Cyclic, Acyclic, Endometritic and Pregnant Crossbred Cows. Int.J.Curr.Microbiol.App.Sci. 8(03): 536-542. doi: https://doi.org/10.20546/ijcmas.2019.803.065 